\title{
KEEPING OF STINGLESS BEES BY THE KAYAPO' INDIANS OF BRAZIL
}

\author{
DARRELL A. POSEY \\ Laboratório de Ethobiologia, Dept. de Biologia \\ Universidade Federal do Maranhão \\ 65.000 São Luís, Maranhão, Brazil
}

\begin{abstract}
The Kayapo Indians of Brazil recognize 56 folk species of stingless bees, with an 86 per cent correlation with scientific classifications. Of these, nine species are considered semi-domesticates. Honey is an important nutritional element in the Kayapo diet; beeswax is believed to be a material link with the ancient world and is used to form a ceremonial hat (mekutom) that is a model of the universe.
\end{abstract}

\section{INTRODUCTION}

Previously I have pointed out the widespred use of insects by indigenous peoples in the lowland tropics of the New World (Posey 1978a, 1978b, 1980). Inevitably stingless bees (Meliponidae) are one of the most valued insect resources. Beekeeping for the Maya of Mesoamerica, for example, was an elaborate science (Schwarz 1948). For the Kayapo Indians of the middle Xingu region of Brazil, beekeeping is not as complicated as that of the Maya; however, knowledge and utilization of stingless bees is well-developed.

There are approximately $2,500 \mathrm{Ge}$-speaking Indians in the Kayapo nation, which is divided into nine widely dispersed villages in a two-million hectare reserva indigena in the Brazilian states of Pará and Mato Grosso. The data used in this paper were collected at Gorotire (7048's, $5107^{\prime} \mathrm{W}$ ), the largest village (population approximately 600 ), during a 14-month field study conducted in 1977-78 (See Fig. 1).

As an athropologist with entomological training, I was initially attracted to the role of bees in the Kayapo culture by the elaborate semantic domain of social insects and by the extensive mythological corpus collected about social insect (Posey 1981a, in press). Social communities of Hymenoptera are thought to mirror Kayapo communities; indeed, it is believed that Indians learned how to live as social beings from an ancestral wise man (wayanga), who gained his knowledge from the study of bee, wasp, and ant behavior (Posey 1978a, 1979). This belief serves as a social charter to the Kayapo to continue their observations of nature in general and of Hymenoptera in particular and accounts for their reputation as keen ethologists (Posey 1981a, 1981b).

\section{THE SOCIAL AND ECOLOGICAL CONTEXT}

The Kayapo are excellent agriculturalists, but rely upon gathered foods as a major portion of their diet (cf. Bamberger 1967). The thoroughness of their ecological exploitation, and the wide variety of plants and animals utilized from that exploitation, have allowed the Kayapo to range over a variety of ecological zones effectively (Posey 1979, 1982).

The Kayapo recognize three major ecological zones:

1. kapot (campo) of which there are our types:

a. kapot-kên - campos with short grasses;

b. kapot-kamepti-campos with trees;

c. kapot-kam-bõiprek - campos with high grasses;

d. pykati'ô'krãi - campos with intermittant trees.

2. krãi (mountains), and

3. bà (forest) of which there are four types:

a. bà-kamrek - gallery or riverine forest; 


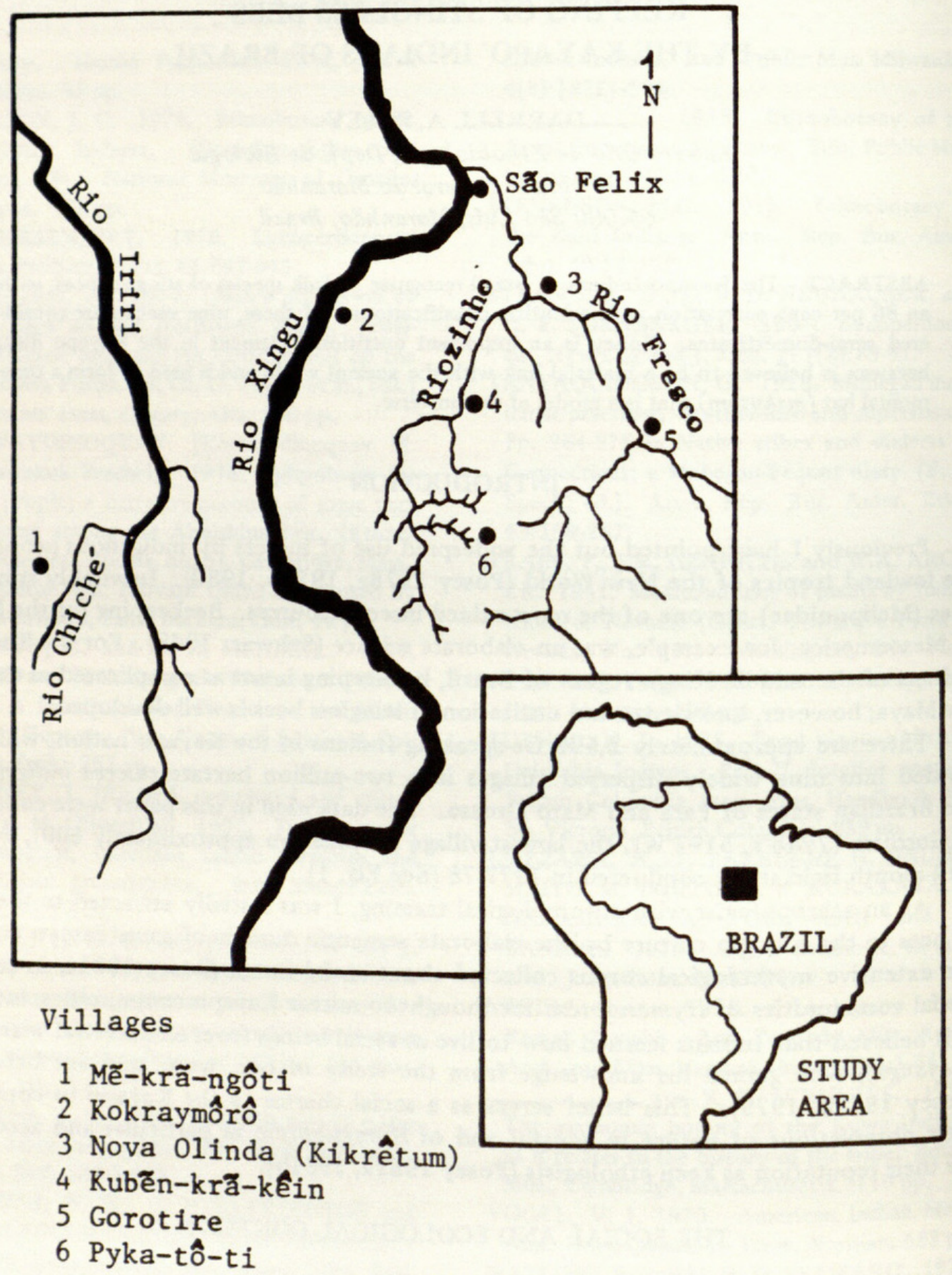

FIG. 1.-General Geographic Orientation of the Kayapo Indian Villages of Central Brazil.

b. bà-epti-dense jungle;

c. bàkati or pi 'y-ko - high forest; and

d. bà-bàràrà - forest with intermittent openings.

Native consultants (informants) were able to group stingless bees under these ecological zones with consistency, reflecting the various habitats frequented by the specific folk species of bees.

A morphological taxonomic system also exists, but the ability of the Indians to identify most bees out of their habitats is unreliable. A few species are widely known by men and women and can even be identified away from their nests (eg., Apis mellifera, Melipona rufiventris flavolineata, and Trigona dallatorreana). These are recognized by 
general morphological features such as body color, markings, and relative size. Out of a village population of approximately 600 , I found only two bee "experts" who are reasonably consistent in identifying folk species from morphological characteristics alone. Both bee specialists were males. Women know little about bees since the collection of honey and wax rests within the male social domain.

During the dry season, groups of men often go off for days to procure honey. Honey is constantly sought on hunting trips and is highly prized. Meat and gathered foods are generally brought to the village and given to the wife or wife's mother (the eldest female of the household). She then distributes the meat or produce as she pleases among relatives. This is not the case with honey: a man is free to distribute honey as he pleases. Rarely does any honey ever reach the village, however, for it is usually drunk at the collection site.

The Indians make honey containers on the spot from multiple layers of banana leaves. The leaves are folded upward to form a collection vessel. When no honey remains in the vessel, the leaves are licked to glean the last drops that may have escaped through the leaf cracks.

The Kayapo masticate the thick bases of stalks of wild ginger until an absorbant brush-like object is produced. This is dipped into the honey and pulled through the mouth. This is an efficient way for several people to consume honey at the same time. Some Kayapo dispense with any proprieties and drink the honey like water. I have no data on how much honey is consumed by the average Kayapo in a year's time; however, I have seen a single Indian boy drink a half-liter of honey in one sitting. The Kayapo men like to drink honey until they feel light-headed (Posey 1981b).

Often sections of the nest combs that are filled with larvae, pupae, or pollen are also eaten. These have a very light, wafer-like texture and taste and are excellent when eaten with the honey and are as highly-prized as the honey itself (Table 1).

When honey is removed from the hive, a portion of the brood comb and honey is always left behind for Bep-kororoti, a powerful shaman who was taken into the sky in a flash of lightning. Functionally this secures the perpetuation of certain species that will return to re-colonize (Table 2). He resides in the clouds, or rather is the clouds, and sends lightning, thunder, and rain. Anyone who does not share with Bep-kororoti and his fellow Kayapo risks being struck by lightning.

Honey, wax, and bees are associated with the heavens and rains because of Bepkororoti's penchant for honey. Bees wax is burned to produce a smoke that is believed to attract storm clouds and rains. The smoke is also believed to repel evil spirits, purge houses from lingering ancestral spirits, and protect children from witchcraft (cf. Posey $1981 \mathrm{~b}$, in press).

Beeswax is also used for many Kayapo artifacts. In most cases I was unable to ascertain if the bees wax had special ceremonial importance in artifact production, or if it served purely functional purposes.

Feathers and bow points are cemented into arrows with bees wax. Wax is also used to strengthen and lubricate bow strings. Black wax is used to darken cotton string that is used in making various wooden and bone artifacts (Posey 1978, in press).

The most impressive article made from bees was is the me-kutom, a hat worn by young men about to receive ceremonial names. The beeswax for these hats is inherited and stored as a ball in a hole in the earthen floor of the family's house. At the time of a name-giving ceremony, the wax ball is exhumed and formed into the me-kutom by a male relative of the boy.

The form of the me-kutom is highly symbolic (Figure 2). The front point of the me-kutom is called the "morning sky pole" (kaikwa kratx); the rounded back is the "evening sky pole" (kaikwa-not). These poles represent the beginning and ending points of the sun's path across the sky. The two "legs" (pa) are equivalent to north and south cardinal directions. There are painted patches on the pa that represent the idealized geographical relationships between village and fields. The village is the nipok, or center 
TABLE 1.-Principal species of Apidae utilized by the Kayapo Indians.

\begin{tabular}{|c|c|c|c|c|c|c|c|c|c|c|c|c|}
\hline Kayapo Name & Scientific Name & Util. & $\begin{array}{l}\text { Wax Use } \\
\text { Cer. }\end{array}$ & Med. & Seasonal & $\begin{array}{l}\text { Honey } \\
\text { Amount }\end{array}$ & $\begin{array}{l}\text { Larvae } \\
\text { Eaten }\end{array}$ & $\begin{array}{l}\text { Pupae } \\
\text { Eaten }\end{array}$ & $\begin{array}{l}\text { Pollen } \\
\text { Eaten }\end{array}$ & $\begin{array}{l}\text { Resin } \\
\text { Used }\end{array}$ & $\begin{array}{l}\text { Aggres- } \\
\text { sive* }^{*}\end{array}$ & Distinctive Traits \\
\hline ngài-pere-y & Apis mellifera & $\mathbf{x}$ & $\mathbf{x}$ & & all year & very much & & & $\mathbf{x}$ & & +++ & $\begin{array}{l}\text { Honey taken during } \\
\text { New Moon }\end{array}$ \\
\hline ngài-ny-tyk-ti & M. semiligra & $\mathbf{x}$ & $\mathbf{x}$ & $\mathbf{x}$ & dry seas. & average & & & & & ++ & $\begin{array}{l}\text { Bee parts used for hunting } \\
\text { magic }\end{array}$ \\
\hline ngài-kumrenx & M. rufiventris & $\mathbf{x}$ & $\mathbf{x}$ & $\mathbf{x}$ & all year & average & & & & & & Wax used for me-kutom \\
\hline ngài-re & M. compressipes & $\mathbf{x}$ & $\mathbf{x}$ & $\mathbf{x}$ & all year & much & & & & & & $\begin{array}{l}\text { Has markings like the } \\
\text { "anta" }\end{array}$ \\
\hline ngài-kàk-ñy & Partamona sp. & & & & & & & & & & & $\begin{array}{l}\text { Was used in magic to make } \\
\text { enemy weak }\end{array}$ \\
\hline $\begin{array}{l}\text { mykrwãt } \\
\text { udjy }\end{array}$ & $\begin{array}{l}\text { Frieseomelitta sp. } \\
\text { T. amalthea }\end{array}$ & $\mathbf{X}$ & $\mathbf{x}$ & $\mathrm{x}$ & $\begin{array}{l}\text { all year } \\
\text { dry seas. }\end{array}$ & $\begin{array}{l}\text { average } \\
\text { average }\end{array}$ & $\mathbf{x}$ & $\mathbf{x}$ & $\mathrm{x}$ & $\mathrm{X}$ & & $\begin{array}{l}\text { Bee parts mixed with } \\
\text { urucu for hunting magic }\end{array}$ \\
\hline kukraire & T. dallatorreana & & & & all year & much & & & $\mathbf{x}$ & & + & $\begin{array}{l}\text { Break off limb with nest } \\
\text { and run to expell bees }\end{array}$ \\
\hline mehnorã-kamrek & T. cilipes & & & $\mathbf{x}$ & all year & little & & & & $\mathbf{x}$ & & Has skinny eyes like jaguar \\
\hline mehnorã-tyk & Scaura longula & & & $\mathrm{x}$ & all year & little & & & & $\mathrm{x}$ & & $\begin{array}{l}\text { Used for jaguar hunting } \\
\text { magic }\end{array}$ \\
\hline $\begin{array}{l}\text { kagnàrà-krã- } \\
\text { kamrek }\end{array}$ & O. tataira & $\mathbf{x}$ & $\mathbf{x}$ & $\mathbf{x}$ & all year & average & $\mathrm{X}$ & $\mathrm{X}$ & $\mathrm{X}$ & & ++ & $\begin{array}{l}\text { Cut entire tree to take } \\
\text { honey }\end{array}$ \\
\hline kangàrà-krã-tyk & Oxytrigona sp. & $\mathrm{X}$ & $\mathrm{X}$ & $\mathbf{x}$ & all year & average & $\mathbf{x}$ & $\mathrm{X}$ & $\mathbf{x}$ & & ++ & Bee causes blisters on skin \\
\hline kangàrà-udja-ti & Oxytrigona sp. & $\mathbf{X}$ & $\mathbf{x}$ & $\mathbf{x}$ & all year & average & $\mathbf{x}$ & $\mathbf{x}$ & $\mathbf{x}$ & & +++ & Bees used in hunting magic \\
\hline kangàrà-ti & Oxytrigona sp. & $\mathrm{X}$ & $\mathbf{x}$ & $\mathrm{X}$ & all year & average & $\mathrm{x}$ & $\mathrm{X}$ & $\mathrm{X}$ & & +++ & Wax used for me-ktuom \\
\hline myre & T. pallens. & $\mathrm{x}$ & $\mathbf{x}$ & $\mathbf{x}$ & all year & average & & & & & + & Sometimes fell tree \\
\hline ngoi-tenk & Trigona sp. & & $\mathbf{x}$ & & all year & average & & & & & & Live in termite nests \\
\hline djô & T. fuscipennis & $\mathrm{x}$ & $\mathbf{x}$ & $\mathrm{x}$ & all year & little & & & & & & Live in termite hills \\
\hline imre-ti-re & T. chanchamayoensis & & & & all year & little & $\mathrm{X}$ & $\mathrm{X}$ & $\mathrm{x}$ & & & Live in ant nests \\
\hline kukoire-ka & Partamona sp. & & & & all year & average & & & & & + & Nests in termite nests \\
\hline o'i & Tetragona sp. & & & & dry seas. & little & & & & & & $\begin{array}{l}\text { Very acidic honey; fell } \\
\text { entire tree }\end{array}$ \\
\hline
\end{tabular}


TABLE 1.-Principal species of Apidae utilized by the Kayapo Indians (continued)

\begin{tabular}{|c|c|c|c|c|c|c|c|c|c|c|c|c|}
\hline Kayapo Name & Scientific Name & Util & Wax U & & Seasonal & oney & Larvae & Pupae & Pollen & $\begin{array}{l}\text { Resin } \\
\text { Used }\end{array}$ & $\begin{array}{l}\text { Aggres- } \\
\text { sive }\end{array}$ & Distinctive Traits \\
\hline ton-my & Tetragona sp. & $\mathbf{x}$ & $\mathbf{X}$ & $\mathbf{x}$ & dry seas. & average & & & & $\mathbf{x}$ & & Fell tree to take honey \\
\hline ri & Tetragona sp. & $\mathrm{x}$ & $\mathbf{x}$ & $\mathrm{x}$ & all year & much & & & & $\mathrm{x}$ & & $\begin{array}{l}\text { Bee thought to be } \\
\text { "stupid" and weak }\end{array}$ \\
\hline mehn-xi-we'i & Tetragona goettei & $\mathbf{X}$ & $\mathbf{x}$ & $\mathbf{X}$ & all year & average & & & & & & Found only in the Xingu \\
\hline menire-udja & T. quadrangula & $\mathrm{x}$ & $\mathbf{x}$ & $\mathbf{x}$ & all year & average & & & & & & $\begin{array}{l}\text { Opening of nest like a } \\
\text { vagina }\end{array}$ \\
\hline mehnodjanh & F. varia & & & $\mathbf{x}$ & dry seas. & little & & & & $\mathrm{x}$ & & $\begin{array}{l}\text { Smoke from wax used for } \\
\text { curing }\end{array}$ \\
\hline mehñykamrek & T. spinnipes & $\mathbf{x}$ & $\mathbf{x}$ & $\mathrm{x}$ & dry seas. & little & $\mathrm{X}$ & $\mathrm{X}$ & $\mathrm{x}$ & & + & $\begin{array}{l}\text { Wax burned; smoke causes } \\
\text { dizziness }\end{array}$ \\
\hline mehñy-tyk & T. banneri & $\mathrm{X}$ & $\mathrm{x}$ & $\mathrm{X}$ & dry seas. & little & & & & & + & \\
\hline pyka-kam & T. fulviventris & $\mathbf{x}$ & $\mathrm{X}$ & $\mathrm{x}$ & dry seas. & little & & & & $\mathrm{x}$ & + & $\begin{array}{l}\text { Bee deposits drops of resin } \\
\text { on skin }\end{array}$ \\
\hline
\end{tabular}

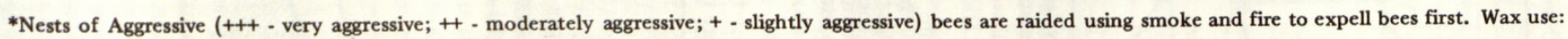

Utilitarian; Ceremonial; Medicinal. 
TABLE 2.-Semi-domesticated (manipulated) species of APIDAE utilized by the Kayapo.

\begin{tabular}{|c|c|}
\hline Kayapo Name & Scientific Name \\
\hline *Ngài-pere-y & Apis mellifera Linn. \\
\hline$*+N g a ̀ i-n ̃ y-t y k-t i$ & Melipona seminigra $c f$. pernigra (Moure \& Kerr) \\
\hline $\begin{array}{l}\text { *†Ngài-kumrenx } \\
\quad \text { (mehn-krak-krak-ti) }\end{array}$ & Melipona rufiventris flavolineata (Friese) \\
\hline *Ngài-re & $\begin{array}{l}\text { Melipona compressipes } c f . \text { fasciculata (Smith) or } \\
\text { afinis Moure Ms. }\end{array}$ \\
\hline *mykrwat & Frieseomelitta sp. \\
\hline *tudjy & Trigona amalthea (Olivier) \\
\hline *+kukraire & Trigona dallatorreana Friese \\
\hline mehnorã-kamrek & Trigona cilipes pellucida (Ckll.) \\
\hline mehnorã-tyk & Scaura longula (Lep.) \\
\hline
\end{tabular}

$\lceil$ Those species whose nests are taken to the village.

Those species that are encouraged to build nests in dry posts in the houses.

*These species are systematically raided in subsequent seasons.

circle. The circle also represents the sun. The smaller circle inside the nipok represents the moon superimposed over the sun. The painted paths from the sky poles indicate the paths of the sun and moon through the sky (kaikwa) and over the earth (pyka).

From a side view (Figure 3), the me-kutom represents another plane and the relationship between sky and earth. The wax hat itself is seen as a floating somewhat concave, disc with small "feet" ( $p a)$. The circle (nipok) as seen from above is really an elevated hump into which is inserted a thin stick. Onto the stick is woven an arch of bamboo and cotton. Macaw feathers are inserted into the bamboo to produce a radiating arc of red and blue feathers. This represents the sky (kaikwa). The Kayapo believe they once lived above the sky and lowered themselves to the earth by means of a woven cotton rope that was dropped through an armadillo hole. The stick represents the cotton string that once brought the Kayapo from the upper world to the earth (Posey 1981b).

It is said that the wax used for the me-kutom is the same as that brought by the ancient Kayapo from the sky. It is a direct and highly valued link with the very origins of Kayapo culture. It is the one material continuity the Kayapo of today have with their most ancient ancestors.

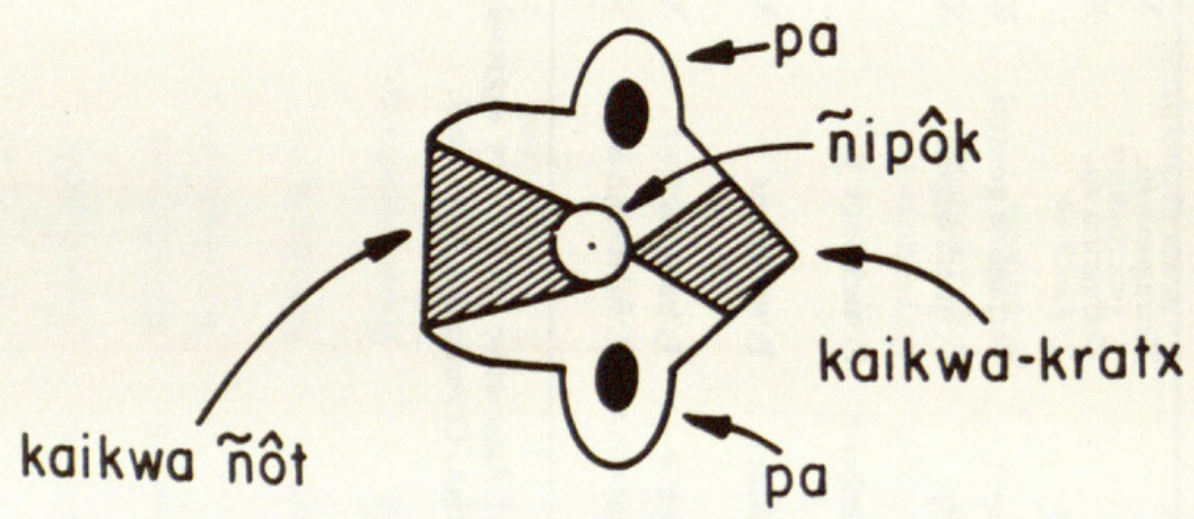

FIG. 2.-An Overview of the me-kutom, showing major symbolic components. 


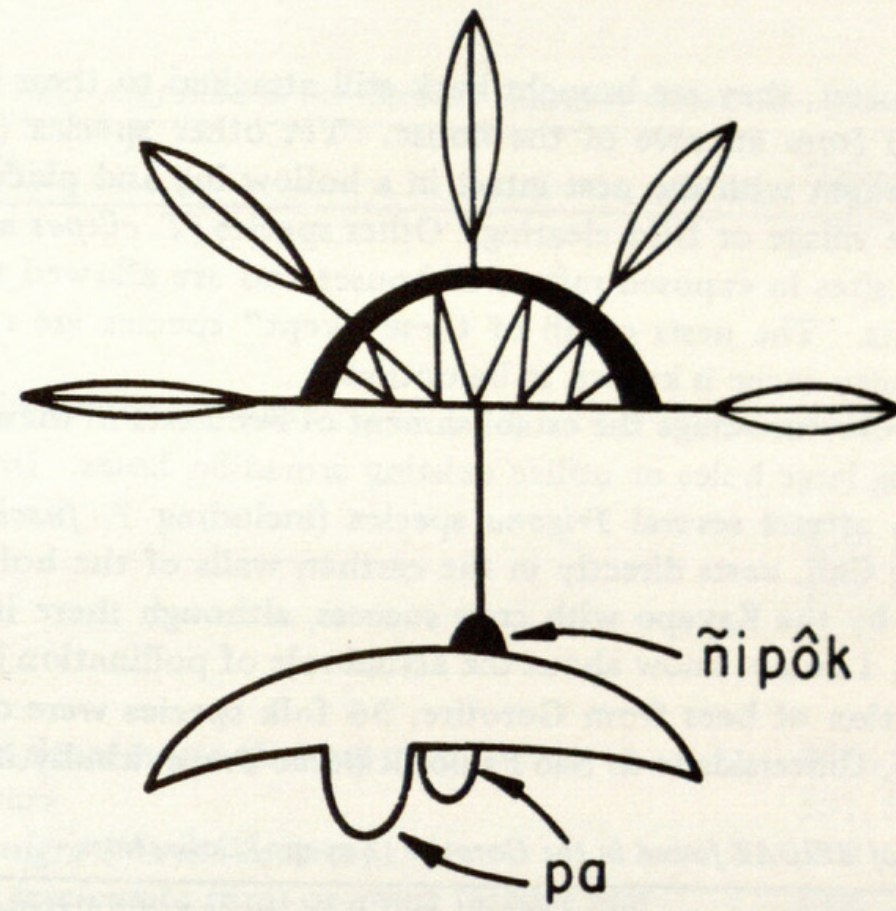

FIG. 3.-A lateral view of the me-kutom, showing the symbolic relationships between earth (pyka) and sky (kaikwa).

\section{CLASSIFICATION AND BEEKEEPING}

As is frequently discovered in folk biology, several taxonomic systems seem to be superimposed and a particular classification paradigm brought to play depending on functional context (Gardner 1976). One "functional" classification system is based on the aggressive behavior of the bee when disturbed. There are four major divisions in this system: (1) docile, (2) stinging, (3) biting, and (4) blister-causing. The two "stinging" bees are the non-native European and the hybrid Brazilian bee (Apis mellifera).

This Brazilian bee is a source of great concern for the Kayapo because of its aggressive behavior. Since its arrival in the area (the Indians say it arrived in 1966 during the February full moon), the Brazilian bee has driven out or taken over the nests of native bees. The Kayapo claim that the availability of native bee honey has drastically declined because of the colonizing exuberance of the Apis mellifera. The Kayapo have grown to like the abundant, sweet honey of the Apis mellifera (ngai-pere'y), but still prefer the flavor of the honey from stingless bees.

There is an elaborate system of bee classification based on nest structure and location of the nest. Nests are grouped by: (1) nest site (in a tree, in the earth, in vines, in abandoned termite hills, etc.); (2) the height of the nest from the ground; (3) the shape and size of the entrance tube (length, shape, markings, size, etc.); and (4) nest size (based on gross size, relative amount of honey per nest, etc.). These criteria correlate closely with Willie and Michener's (1973) descriptive typology.

Nests are raised using strategies consistent with the aggressive nature of the species. For the most violent bees (akre), fire and smoke are used to expel the colony before the nest is opened. If the nest is high up in a tree, the entire tree will be felled in order to get the nest. For less aggressive species (wajobore), the Indians tackle the nest with axes and bare hands, despite clouds of furious, swarming insects (Posey 1981b). Table 1 summarizes characteristics of principal species recognized by the Kayapo.

The Kayapo recognize six species whose nests can be raided and, if the queen and part of the brood chamber are returned to the nest, the bees will return to re-establish the colony. Thus there are trees known by, and in a sense owned by, certain Kayapo men that are consistently raided year after year (Table 2).

The Kayapo also "keep" several species in or nearby their houses. For example when nests of certain species of Trigona ( $T$. dallatorreana and one unidentified species) 
are found in the forest, they are brought back still attached to their limbs and the complete nests erected from an eave of the house. Yet other species (T. amlthea and $M$. rufiventris) are brought with the nest intact in a hollow log and placed at the margin of the forest near the village or field clearing. Other species (T. cilipes and S. longula) tend to prefer building sites in exposed rafters of houses and are allowed to co-exist with the household residents. The nests of all of these "kept" species are raided at prescribed times when the honey cache is known to be optimal.

The Kayapo also encourage the establishment of bee nests in their fields. To do this, they sometimes dig large holes or utilize existing armadillo holes. Into these holes they place logs, which attract several Trigona species (including T. fuscipennis Friese). $T$. fulviventris guinae Ckll. nests directly in the earthen walls of the hole. The presence of bees is associated by the Kayapo with crop success, although there is no clear notion of pollination per se. I do not know about the actual role of pollination by these species.

In my collection of bees from Gorotire, 56 folk species were discerned (Table 3). J. M. F. Camargo, Universidade de Sao Paulo, Riberao Preto, kindly inspected and identi-

TABLE 3.-Species of APIDAE found in the Gorotire (Kayapo) Collection.

\begin{tabular}{ll}
\hline Family, Genus, Species & Collection Code Number ${ }^{1}$ \\
\hline
\end{tabular}

\section{ANTHRPHORIDAE}

Xylocopa (Schoenherria) dimidiata Latr.

$540-2$

$X$. (Schoenherria) lucida Smith

$112-1$

$X$. (Schoenherria) anthophoroides Smith

$X$. (Megaxylocopa) frontalis (Oliver)

$507-1$

$540-1$

Centris (Centris) inermis Friese

C. (Centris) flavifrons (Fab.)

C. (Centris) aenia Lep.

C. (Centris) spilopoda Moure

$422,479-6$

C. (Paremisia) similis (Fab.)

sem no- 1

sem no -1

$117-1$

442 - 2

C. (Paremisia) dentata Smith

442 - 3

C. (Trachina) longimana (Fab.)

540 - 2

C. (Heterocentris) bicornuta Mocs.

$103,104-2$

C. (Centris) sp 1

C. (Centris) sp 2

$113,114-2$

C. (Paremisia) sp

C. (Hemisiella) sp

C. (Melanocentris) sp

$111-1$

$35-1$

$105-1$

$119,120,118-3$

Mesoplia sp (parasita)

Mesonychium asteria (Smith) (parasita)

$278-1$

$603-1$

Tetrapedia sp

222 - 1

HALICTIDAE

Halictus hesperus (Smith)

Neocorynura sp

Augochloropsis sp

$88-2$

$280-1$

$451-1$

MEGACHILIDAE

Megachile brasiliensis DallaTorre

M. (Austromegachile) sp

$M$. (Crysosaurus) sp

$M$. cf. giraffa Schrottky

Megachile sp 3

Megachile sp 2

Megachile sp 1 
TABLE 3.-Species of APIDAE found in the Gorotire (Kayapo) Collection. (Continued)

Family, Genus, Species

Collection Code Number

\section{APIDAE}

Bombinae

Euglossini

Eulaema (Eulaema) meriana (Olivier)

$540-2$

Apinae

Apis mellifera (L.)

$218,109,106$, $110,108,340$

Meliponinae

Meliponini

Melipona rufiventris flavolineata (Friese)

$547-2$

M. tumupasae Schwarz

M. seminigra cf. pernigra (Moure \& Kerr)

$331,541,332,325-4$

$340-1$

M. compressipes $c f$. fasciculata $(\mathrm{Sm})$ or afinis (Moure $\mathrm{Ms}$ )

$542-1$

\section{TRIGONONI}

Paratrigona (Paratrigona) cf. peltata (Spinola)

$554-1$

Oxytrigona tataira $c f$. flaveola (Friese)

$555,553-4$

Plebeia (Plebeia) minima (Gribodo)

$520-1$

Scaura (Scaura) longula (Lep.)

Cephalotrigona capitata femorata (Smith)

sem no- 1

$509-1$

Trigona (Trigona) spinipes (Fab.)

$328-6$

$T$. (Trigona) fuscipennis Friese

$557,89,71-6$

$T$. (Trigona) amalthea (Olivier)

$343,504,475,94$,

$343-7$

T. (Trigona) fulviventris guianae Ckll.

$T$. (Trigona) chanchamayoensis Schwarz

$466-1$

$44-1$

$515-1$

$T$. (Trigona) pallens pallens

sem no - 1

$T$. (Trigona) cilipes pellucida (Ckll.)

$T$. (Trigona) dallatorreana Friese

$546,473-3$

$T$. (Trigona) branneri Ckll.

516 - 2

Partamona (Partamona) pseudomusarum Camargo

$512-7$

$P$. (Partamona) cf. cupira (Smith)

P. (Partamona) sp 1

P. (Partamona) sp 2

$96-1$

334,356 ? - 2

$581-1$

$339,550-5$

$342-3$

$432,512-3$

$436,437,435-9$

$522,338-4$

$536,327,506-11$

$86-1$

$604-1$

$508-2$

$519,513-3$

$85-1$

$558-5$ 
fied the Gorotire collection. He found 66 scientifically recognized species of which 11 were unknown or as yet not described (one species of Frieseomelitta; two of Partamona; one of Tetragona; two of Centris; three of Megachile; one of Mesoplia; and one of Tetrapedia).

In a normative comparison between folk and scientific species, therefore, we find that there is approximately an $86 \%$ correlation. Such high correlative quotients are not uncommon (Berlin 1973, Hunn 1975). The complete species list is found in Table 3.

\section{CONCLUSION}

Bees and other social insects are of great symbolic importance to the Kayapo Indians. The organization of the Hymenoptera is believed to be the basis of human social and political organization. Honey and beeswax are directly related to Bepkororoti, a central mythological figure who controls rain and lighning. The beeswax mekutom is a symbolic representation of the Kayapo world and is said to be the one material link to origins of the Kayapo people.

Various folk taxonomic systems operate to classify the 56 folk species of stingless bees recognized by the Kayapo. The Kayapo utilize nine major "ecozones" to group bees by nesting sites. Other taxonomic paradigms take into account specific nest types and exact locations within a given "ecozone." A morphological taxonomy also exists, but appears to be utilized by only a few bee "experts." Utilitarian considerations seem to forge the predominant taxonomic system, taking into account the behavior of the bees, honey taste and wax type.

There is an $86 \%$ correlation between folk species and scientifically determined species listed in Table 3. It is clear that the Kayapo are keen observers of nature in general and Meliponidae in particular. Bees are an important economic source to tropical forest peoples like the Kayapo Indians of Brazil.

\section{ACKNOWLEDGEMENTS}

This research was funded by the Wenner-Gren Foundation for Anthropological Research. I would like to thank the staffs of FUNAI, INPA, CNPq, and the Museu Paraense Emilio Goeldi for their cooperation and assistance. Particularly I would like to acknowledge the assistance of Kwyra-ka and Ira Kayapo; also the continued support of Lauro Menescal, chefe do Posto Gorotire. Without these people, this project would have been impossible. Scientific identification of the insect specimens was graciously provided by J.M.F. Camargo, Faculdade de Medicina, Universidade de Sao Paulo, Riberao Preto, Brazil. To him I am especially grateful.

\section{LITERATURE CITED}

BAMBERGER, JOAN. 1967. Environmental and Cultural Classification: A Study of the Northern Cayapo. Unpubl. Ph.D. dissert. (Anthrop), Harvard Univ.

BERLIN, B. 1973. Folk Systematics in Relation to Biological Classification and Nomenclature. Ann. Rev. Ecol. Syst. 4:259-271.

GARDNER, P. 1976. Birds, Words, and a Requiem for the Omniscient Informant. Amer. Ethnol. 3:446-468.

HUNN, E.S. 1975. A Measure of the Degree of Correspondence of Folk to Scientific Biological Classification. Amer. Ethnol. 2:309-327.

POSEY, D.A. 1978a. Ethnoentomology of the Gorotire Kayapo of Central Brazil. Unpubl. Ph.D. dissert., Univ. of Georgia, Athens. 1978b. Ethnoentomological Sur- vey of Amerind Groups in Lowland Latin America. The Florida Entomol. 61(4):225-229. 1979. Kayapo Controla Insectos com Uso Adequado do Ambiente. Revista de Atualidade Indigena 3(14):47-58.

1980. Algunas Observaciones Etnoentomologicas sobre Grupos Amerindos en la America Latina. America Indigena 15(1): 105-120.

1981a. Wasps, Warriors, and Fearless Men: The Cultural Ecology of the Kayapo Indians of Central Brazil. J. Ethnobiol. 1: 165-174.

1981b. Apicultura Popular dos Kayapo. Revista de Atualidade Indeigena 20(1):36-41.

1982. Development of the Amazon 


\section{LITERATURE CITED (continued)}

on an Indigenous Model. The Dilemma of Amazonian Development (Emilio Moran, ed.). Westview Press.

In press. Ethnomethodology as an

Emic Guide to Cultural Systems: The Case of the Insects and the Kayapo Indians of Amazonia. Anuario Antropologico 82.

In press. The Importance of Bees to the Kayapo Indians of the Brazilian Amazon. Florida Entomol.

In press. Folk Apiculture of the Kayapo Indians of Brazil. Biotropica.
SCHWARTZ, H.F. 1948. Stingless Bees (Miliponidae) of the Western Hemisphere. Bull. Amer. Mus. Nat. Hist. Vol. 90.

TURNER, T. 1965. Social Structure and Political Organization among the Northern Cayapo. Unpubl. Ph.D. dissert., (Social Relations), Harvard Univ.

WILLIE, ALVARO and C. MICHENER. 1973. The Nest Architecture of the Stingless Bees with Special Reference to those of Costa Rica. Revista de Biologia Tropical 21 (Suplemento 1).

\section{NOTES}

The Collection Code Numbers refer to specimens from the Gorotire collection that are now in the possession of J.M.F. Carmargo, Dept. de Biologia, Universidade Federal do Maranhao, 65.000 Sao Luis, MA (Brazil). 


\section{$2 \mathrm{BHL}$ Biodiversity Heritage Library}

Posey, Darrell A. 1983. "Keeping of stingless bees by the Kayapo Indians of Brazil." Journal of ethnobiology 3, 63-73.

View This Item Online: https://www.biodiversitylibrary.org/item/102746

Permalink: https://www.biodiversitylibrary.org/partpdf/183756

\section{Holding Institution}

Missouri Botanical Garden, Peter H. Raven Library

\section{Sponsored by}

Missouri Botanical Garden

\section{Copyright \& Reuse}

Copyright Status: In copyright. Digitized with the permission of the rights holder.

Rights Holder: Society of Ethnobiology

License: http://creativecommons.org/licenses/by-nc-sa/3.0/

Rights: https://biodiversitylibrary.org/permissions

This document was created from content at the Biodiversity Heritage Library, the world's largest open access digital library for biodiversity literature and archives. Visit BHL at https://www.biodiversitylibrary.org. 